ZOOLOGIA 27 (3): 363-371, June, 2010

doi: $10.1590 /$ S1984-46702010000300007

\title{
Archaeozoology of marine mollusks from Sambaqui da Tarioba, Rio das Ostras, Rio de Janeiro, Brazil
}

\author{
Rosa C. C. L. de Souza'; Denise C. Trindade²; Juber de Decco²; Tania A. Lima³ \& Edson P. Silva' \\ ${ }^{1}$ Departamento de Biologia Marinha, Instituto de Biologia, Universidade Federal Fluminense. Outeiro São João Batista, Caixa \\ Postal 100.644, 24001-970 Niterói, Rio de Janeiro, Brazil. E-mail: rcclsouza@yahoo.com.br; gbmedson@vm.uff.br \\ 2 Instituto de Arqueologia Brasileira. Capão do Bispo, Avenida Dom Helder Câmara 4616, 20940-040 Rio de Janeiro, Rio de \\ Janeiro, Brazil. \\ ${ }^{3}$ Departamento de Antropologia, Museu Nacional. Quinta da Boa Vista, 20940-040 Rio de Janeiro, Rio de Janeiro, Brazil.
}

\begin{abstract}
A reference inventory of prehistoric marine mollusks from the Rio das Ostras region was created based on an excavation carried out at the Sambaqui da Tarioba shellmound. Patterns of richness and biogeography were studied, and the representativeness of bivalve and gastropod diversities found at this archaeological site were inferred. A total of 47 taxa belonging to 28 families, most of which from unconsolidated substrates, was identified. The shellmound species composition does not differ from the present-day composition. All recorded species are characteristic of a wide transition zone between the south of the states of Espírito Santo $\left(21^{\circ} \mathrm{S}\right)$ and Rio Grande do Sul $\left(32^{\circ} \mathrm{S}\right)$. Thus, the data show little evidence of evolution in the composition, richness, and biodiversity distribution patterns of mollusks in the Rio das Ostras region. Likewise, a reconstitution of the paleoenvironment from the functional characteristics of the shellmound species indicates that the locality's geomorphology and climate remained largely unchanged in the last 4,000 years BP.

KEY WORDS. Biodiversity; bivalves; gastropods; shellmound.
\end{abstract}

Shellmounds are archaeological sites found in almost all coastal areas around the world that, since a little over a century ago, have been recognized as artificial constructions built by prehistoric human populations (STEIN 1992). In Brazil, particularly between the states of Espírito Santo and Santa Catarina, there are hundreds of shellmounds that attest to the human occupation of the coast between at least 8,000 years ago and the start of the common era (ANDrade Lima et al. 2002, 2003).

The sites chosen for shellmound construction seem to be directly related to food gathering, and they are found near embayments, bays and lagoons, on the interface between marine and terrestrial environments, and between salt and fresh water. The construction of shellmounds in these estuarine environments was not fortuitous, given that these are the environments with the highest biotic productivity on the coast, harboring a high density and diversity of life forms. The biological remains found in shellmounds indicate that the diet of the humans living in those sites was based on shellfish, for they produced wastes with an abundance of very resistant elements such as mollusk shells, crustacean and sea urchin carapaces, fish, bird and mammal bones, etc. (Lima 2000, Figuti 1993).

In addition to information on prehistoric societies, their food supplies and the use of resources for making ornaments and artifacts, the remains found in shellmounds may yield data leading to the examination of other issues. For instance, the fact that these sites contain sets of organisms representative of the flora and fauna existing at the time of their creation makes it possible to recover paleoenvironmental aspects related to species biodiversity and biogeography (Froyd \& Willis 2008, Fürsich 1995, Lindbladh et al. 2007, Scheel-Ybert et al. 2006).

Paleoenvironmental analyses, among other aspects, allow one to infer the impacts caused by climatic changes on community composition (Millar \& Wolfenden 1999). Thus, the definition of an environment's pristine state, generally a necessary condition for the construction of ecological models, cannot dispense with long-term information, which otherwise might compromise the accuracy of these models and therefore restrict their usefulness in management and conservation strategies (PEARSON \& Dawson 2003, ARaújo \& RahbeK 2006, Willis \& Birks 2006).

Another aspect that can be analyzed from archaeological remains is the issue of bioinvasion. Paleoecological studies provide data that can help to understand fundamental issues such as determining the natural expansion of species over time; confirming the status of a species, whether native or exotic; analyzing the rate and patterns of dispersal of invasive species over time; and, finally, assessing the long-term impact of exotic species on native ecosystems (Di CASTRI 1989, Didham et al. 2005).

The knowledge of the biodiversity in a given location should include not only an inventory of living organisms but also an inventory of fossils of the studied region (FURON 1969). 
In other words, a comprehensive approach to the biodiversity issue must include the history of a location, placed on an evolutionary perspective. Thus, based on zooarchaeological research it is possible to recover data about the past and build biodiversity scenarios over time. To that end, it is important to be familiarized with the taxonomic classification, the behavior, and the ecology of organisms, especially with concepts related to biogeography, ecosystems, population ecology, and organism habits and habitats (TCHERNov 1992).

In relation to mollusks, classes Bivalvia and Gastropoda are well represented in shellmound archaeological remains. Therefore, the present study proposes to investigate the mollusk fauna of the Sambaqui da Tarioba shellmound (Rio das Ostras, state of Rio de Janeiro), aiming to create a reference inventory of the marine mollusks that composed the region's prehistoric community. Studies of this nature may constitute valuable tools for a better understanding of the biodiversity and marine biogeography of the Brazilian coast.

\section{MATERIAL AND METHODS}

The archaeological site of Sambaqui da Tarioba, located in the municipality of Rio das Ostras, state of Rio de Janeiro

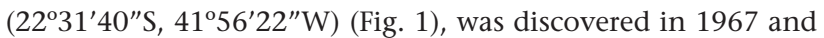
was well preserved at the time. However, the first phase of digging took place only in 1998-99, when $2 / 3$ of the site had already been destroyed. As a result of this digging, the Sambaqui da Tarioba Museum was created, presenting an in situ sample of the material recovered during the excavation. Datings obtained for the site range from 3,620 to 3,440 years BP (Dias 2001).

In 2007, excavation of another part of this site was carried out, which was located on a plot of land next to the museum. Field work consisted in delimiting seventeen $2 \times 2 \mathrm{~m}$ quadrats, for a total of $68 \mathrm{~m}^{2}$ of excavated area. Delayering of the soil was done by artificial 10 -cm layers, revealing the 5 cultural stratigraphic layers which, according to DIAS (2001), constitute the site. The stratigraphic profile became evident when the original soil, prior to human occupation, was reached. In the case of Tarioba Shellmound, in some quadrats it was possible to reach mangrove sand at a depth of $1.4 \mathrm{~m}$; in other quadrats, digging was interrupted before that depth due to the presence of concretions.

Sediment from each sector was collected with mason's trowel, spatula, brush, and shovel and deposited in buckets. So as to facilitate visualization of the smaller elements and to reduce the selection effect of larger remains, the archaeological material was passed through a 5-mm mesh sieve. The malacological material was sorted, packaged, labeled and later sent to the laboratory, where it was washed. Following the SCHEeL-YвERT et al. (2006) protocol, samples were dried naturally, without the aid of ovens, in order to avoid sudden water loss which might cause an increase in shell fragmentation and hamper identification. The malacological material recovered from the excavations was deposited in the collection of the Instituto de Arqueologia Brasileira (Rio de Janeiro, RJ). This study also analyzed the malacological samples obtained in the 1998-99 excavation, also deposited in the same collection.

In addition to taxonomic identification, ecological data on each species, such as habitat, preferred substrate and diet, was investigated in Аввотт (1974), Garcia-Cubas (1981), Rios (1994), Merlano \& Hegedus (1994), Amaral et al. (2005) and MiKKELSEN \& Bieler (2008). Richness and biogeography patterns of the Tarioba Shellmound bivalve and gastropod mollusks were compared to other studies done in Brazil between $22^{\circ} 24^{\prime} \mathrm{S}$ and $25^{\circ} 32^{\prime}$ S - Arquipélago de Santana, RJ (ABSALÃo \& Pimenta 2005); Rio das Ostras, RJ (Coutinho et al. 2005, Globaltech 2002); Lagoa de Araruama, RJ (Silva et al. 2005); Arraial do Cabo, RJ (SoAResGomes \& Fernandes 2005); Ilha Grande, RJ (Santos et al. 2007); São Sebastião, SP (ARRudA et al. 2003, Denadai et al. 2001, 2005) and Paranaguá, PR (BoeHs et al. 2004). Species distribution was analyzed according to the western South Atlantic zoogeographical provinces proposed by PaLACIO (1982).

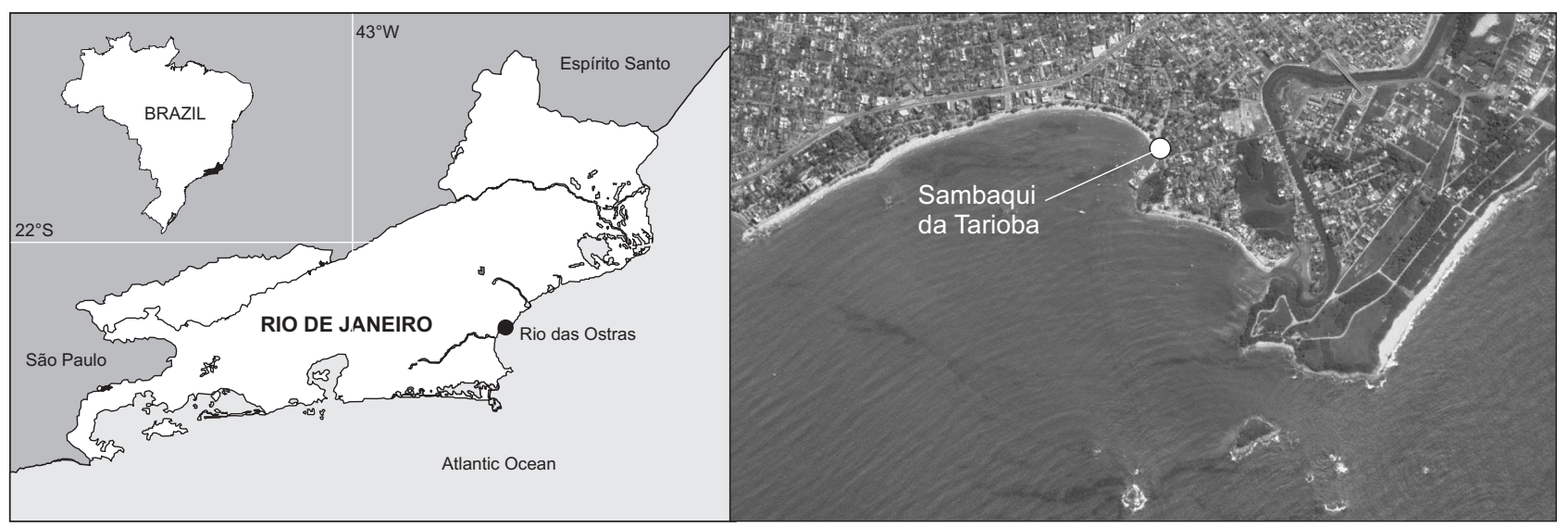

Figure 1. Location of Sambaqui da Tarioba, Rio de Janeiro.

ZOOLOGIA 27 (3): 363-371, June, 2010 
Representativeness of mollusk diversity found at the Tarioba Shellmound was analyzed using the percentage of bivalve and gastropod species in relation to the total number of species recorded for Brazil and for the state of Rio de Janeiro, based on Rios (1994), according to the following criteria: a) distribution in the area comprised between the states of Espírito Santo and Rio Grande do Sul; b) shell greater than $5 \mathrm{~mm}$; c) not being exclusive to oceanic islands; d) benthic; and e) occurring until $200 \mathrm{~m}$ depth.

\section{RESULTS}

Analysis of the malacological remains from the excavations carried out at Tarioba Shellmound led to the identification of 47 taxa belonging to 28 families. Class Bivalvia presented greater richness (27 taxa) than class Gastropoda (20 taxa). Table I provides the inventory of the Tarioba Shellmound mollusk fauna.

Thirteen families of bivalves were recorded, the most representative being Veneridae Rafinesque, 1815 with nine species, followed by Arcidae Lamarck, 1809 and Cardiidae Lamarck, 1809 , both with two species. These three families account for about $48 \%$ of total number of identified bivalves. Gastropods were represented by 15 families, the most common being Olividae Latreille, 1825 with four taxa, followed by Naticidae Forbes, 1838 and Fasciolariidae Gray, 1853, both with two taxa, which combined correspond to $40 \%$ of the total number of identified gastropods.

A visual estimate of the material being retrieved from the digging showed that Iphigenia brasiliana (Lamarck, 1818), popularly known as "tarioba", is the most abundant species in all stratigraphic layers of the shellmound, justifying the site's name. Anadara notabilis (Roding, 1798) and Crassostrea rhizophorae (Guilding, 1828) are also common, followed by Anomalocardia brasiliana (Gmelin, 1791), Trachycardium muricatum (Linnaeus, 1758), Lucina pectinata (Gmelin, 1791), and Pinctada imbricata Roding, 1798. Of family Mytilidae Rafinesque, 1815, only the species Mytella charruana (Orbigny, 1842) was found.

Among gastropods, Cerithium atratum (Born, 1778), Chicoreus senegalensis (Gmelin, 1790), Cymatium parthenopeum (von Salis, 1793), Olivancillaria urceus (Roding, 1798), Stramonita haemastoma (Linnaeus, 1767) and Strombus costatus Gmelin, 1791 are noteworthy.

Most recovered mollusks are beach species (59.5\%), although mangrove, estuary, and lagoon species were also retrieved. About $85 \%$ of the bivalves are unconsolidated substrate species and all are suspensivores. Most gastropods are also unconsolidated substrate species (80\%) although, in this case, $60 \%$ of the recorded species are carnivorous.

According to Palacio's (1982) classification, whereby the zoogeographical provinces of the western South Atlantic are divided into Tropical (from $35^{\circ} 15^{\prime} \mathrm{N}$ to southern Espírito Santo/ Brazil), Paulista (from southern Espírito Santo to southern Rio
Grande do Sul/Brazil), Patagonic (from southern Rio Grande do Sul/Brazil to Cabo Blanco/Argentina) and Malvina (south of Cabo Blanco/Argentina), the species found at Tarioba Shellmound were distributed as follows: Tropical/Paulista (47\%), Tropical/Paulista/Patagonic (32\%), Paulista/Patagonic (17\%) and Paulista (4\%) (Fig. 2).

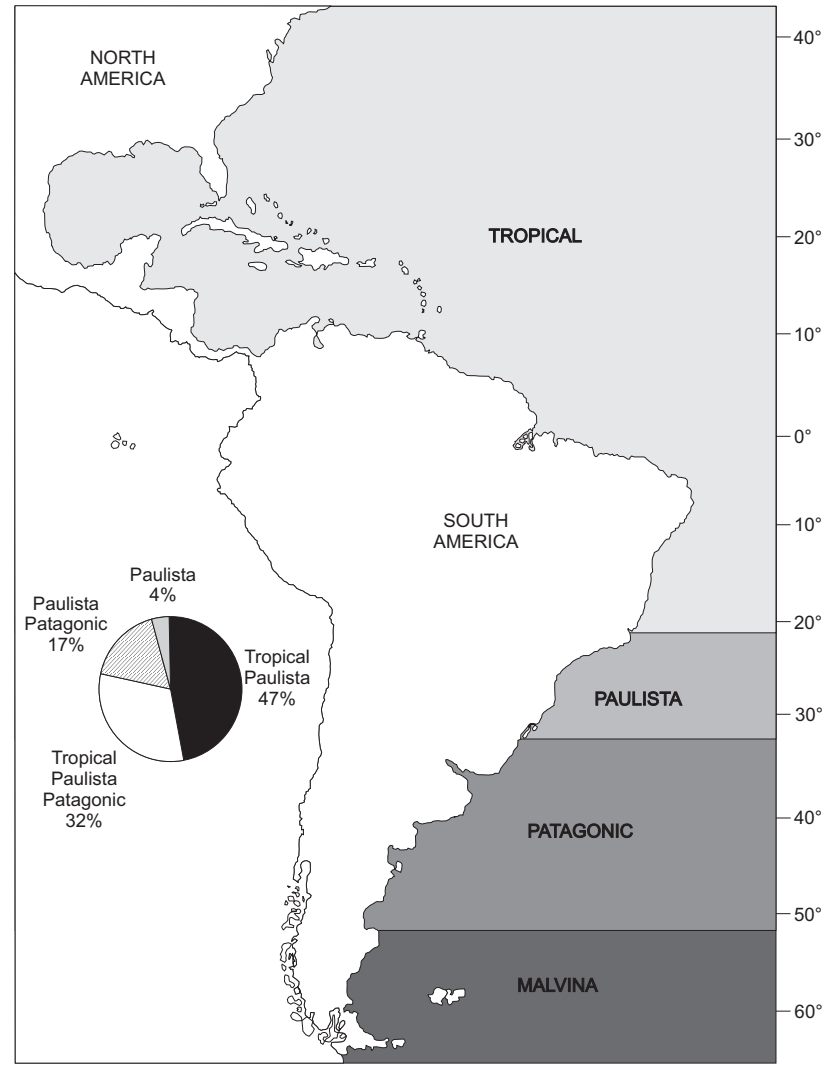

Figure 2. Zoogeographical provinces of the western South Atlantic according to PALACIO (1982) and distribution of bivalve and gastropod species recorded for Sambaqui da Tarioba, Rio de Janeiro.

Table II indicates the species richness data obtained in the present study and compares them to other studies. In absolute terms, the number of identified taxa in this study (47 taxa/1 station) was only surpassed by those found by SANTOS et al. (2007) for the Ilha Grande, RJ region (368 taxa/42 stations), by ABSALÃo \& Pimenta (2005) for Macaé, RJ (146 taxa/17 stations) and by Denadai et al. (2005) for São Sebastião, SP (74 taxa/13 stations).

\section{DISCUSSION}

Many zooarchaeological studies have been carried out in recent years, so as to allow paleoecological interpretations (Roy et al. 2001, Prummel \& Heinrich 2005, Reitz \& Wing 2008). In 
Table I. Inventory of the mollusk fauna at Sambaqui da Tarioba. The category Environment in the table presents obtained information about depth, habitats and marine systems.

\begin{tabular}{|c|c|c|c|c|c|}
\hline \multirow{2}{*}{ Species } & \multicolumn{2}{|r|}{ Ecology } & \multicolumn{3}{|c|}{ Distribution (Western Atlantic) } \\
\hline & Environment & Substrate & Feeding & Provinces & Depth (m) \\
\hline \multicolumn{6}{|l|}{ Bivalvia } \\
\hline \multicolumn{6}{|l|}{ Arcidae } \\
\hline Anadara chemnitzi & subtidal & unconsolidated & suspensivorous & Tropical, Paulista and Patagonic & $5-75$ \\
\hline Anadara notabilis & beach & unconsolidated & suspensivorous & Tropical/Paulista & $0-10$ \\
\hline Anadara ovalis & subtidal, beach & $\begin{array}{l}\text { consolidated, unconsolidated, } \\
\text { epibiotic }\end{array}$ & suspensivorous & Tropical, Paulista and Patagonic & $0-35$ \\
\hline Arca imbricata & subtidal & consolidated and epibiotic & suspensivorous & Tropical/Paulista & $0-10$ \\
\hline \multicolumn{6}{|l|}{ Glycymerididae } \\
\hline Glycymeris longior & subtidal & unconsolidated & suspensivorous & Paulista/Patagonic & $10-75$ \\
\hline Glycymeris undata & beach & unconsolidated & suspensivorous & Tropical/Paulista & $2-55$ \\
\hline \multicolumn{6}{|l|}{ Mytilidae } \\
\hline Mytella charruana & mangrove & consolidated and epibiotic & suspensivorous & Tropical, Paulista and Patagonic & $0-10$ \\
\hline \multicolumn{6}{|l|}{ Pteriidae } \\
\hline Pinctada imbricata & subtidal, mangrove & consolidated and epibiotic & suspensivorous & Tropical/Paulista & $0-10$ \\
\hline \multicolumn{6}{|l|}{ Ostreidae } \\
\hline Crassostrea rhizophorae & mangrove & consolidated and epibiotic & suspensivorous & Tropical, Paulista and Patagonic & $0-30$ \\
\hline \multicolumn{6}{|l|}{ Lucinidae } \\
\hline Lucina pectinata & $\begin{array}{l}\text { beach, estuary, } \\
\text { lagoon, mangrove }\end{array}$ & unconsolidated & suspensivorous & Tropical/Paulista & $0-10$ \\
\hline \multicolumn{6}{|l|}{ Ungulinidae } \\
\hline Phlyctiderma semiaspera & subtidal & unconsolidated & suspensivorous & Tropical, Paulista and Patagonic & $5-100$ \\
\hline \multicolumn{6}{|l|}{ Cardiidae } \\
\hline Trachycardium muricatum & beach, lagoon & unconsolidated & suspensivorous & Tropical, Paulista and Patagonic & $0-30$ \\
\hline Laevicardium brasilianum & beach & unconsolidated & suspensivorous & Tropical, Paulista and Patagonic & $0-70$ \\
\hline \multicolumn{6}{|l|}{ Mactridae } \\
\hline Mactra isabelleana & subtidal, beach & unconsolidated & suspensivorous & Paulista/Patagonic & $0-10$ \\
\hline \multicolumn{6}{|l|}{ Semelidae } \\
\hline Semele proficua & beach & unconsolidated & suspensivorous & Tropical, Paulista and Patagonic & $0-75$ \\
\hline \multicolumn{6}{|l|}{ Solecurtidae } \\
\hline Tagelus plebeius & estuary & unconsolidated & suspensivorous & Tropical, Paulista and Patagonic & $0-10$ \\
\hline \multicolumn{6}{|l|}{ Donacidae } \\
\hline Donax hanleyanus & beach & unconsolidated & suspensivorous & Paulista/Patagonic & $0-10$ \\
\hline Iphigenia brasiliana & beach, estuary & unconsolidated & suspensivorous & Tropical, Paulista and Patagonic & $0-10$ \\
\hline \multicolumn{6}{|l|}{ Veneridae } \\
\hline Ventricolaria rigida & beach & unconsolidated & suspensivorous & Tropical/Paulista & $10-100$ \\
\hline Chione paphia & beach & unconsolidated & suspensivorous & Tropical, Paulista and Patagonic & $10-100$ \\
\hline Anomalocardia brasiliana & beach, lagoon & unconsolidated & suspensivorous & Tropical, Paulista and Patagonic & $0-30$ \\
\hline Protothaca antiqua & subtidal, beach & unconsolidated & suspensivorous & Paulista/Patagonic & $0-30$ \\
\hline Tivela mactroides & beach & unconsolidated & suspensivorous & Tropical/Paulista & $0-30$ \\
\hline Pitar fulminatus & beach & unconsolidated & suspensivorous & Tropical/Paulista & $0-30$ \\
\hline
\end{tabular}


Table I. Continued.

\begin{tabular}{|c|c|c|c|c|c|}
\hline \multirow{2}{*}{ Species } & \multicolumn{2}{|r|}{ Ecology } & \multicolumn{3}{|c|}{ Distribution (Western Atlantic) } \\
\hline & Environment & Substrate & Feeding & Provinces & Depth $(m)$ \\
\hline Amiantis purpuratus & beach & unconsolidated & suspensivorous & Paulista/Patagonic & $0-30$ \\
\hline Macrocallista maculata & beach & unconsolidated & suspensivorous & Tropical/Paulista & $0-100$ \\
\hline Dosinia concentrica & beach & unconsolidated & suspensivorous & Tropical/Paulista & $0-60$ \\
\hline \multicolumn{6}{|l|}{ Gastropoda } \\
\hline \multicolumn{6}{|l|}{ Trochidae } \\
\hline Tegula viridula & intertidal & consolidated & herbivorous & Tropical/Paulista & $0-10$ \\
\hline \multicolumn{6}{|l|}{ Turbinidae } \\
\hline Astraea latispina & intertidal & consolidated & herbivorous & Tropical/Paulista & $0-10$ \\
\hline \multicolumn{6}{|l|}{ Neritidae } \\
\hline Neritina virginea & $\begin{array}{l}\text { estuary, lagoon, } \\
\text { mangrove }\end{array}$ & unconsolidated and epibiotic & herbivorous & Tropical/Paulista & $0-10$ \\
\hline \multicolumn{6}{|l|}{ Cerithidae } \\
\hline Ceritium atratum & beach, lagoon & $\begin{array}{l}\text { consolidated and } \\
\text { unconsolidated }\end{array}$ & herbivorous & Tropical/Paulista & $0-30$ \\
\hline \multicolumn{6}{|l|}{ Strombidae } \\
\hline Strombus costatus spectabilis & subtidal & unconsolidated and epibiotic & herbivorous & Tropical/Paulista & $5-40$ \\
\hline \multicolumn{6}{|l|}{ Calyptraeidae } \\
\hline Crepidula aculeata & subtidal & unconsolidated and epibiotic & herbivorous & Tropical, Paulista and Patagonic & $12-36$ \\
\hline \multicolumn{6}{|l|}{ Naticidae } \\
\hline Natica canrena & subtidal, beach & unconsolidated & carnivorous & Tropical/Paulista & $0-30$ \\
\hline Polinices hepaticus & subtidal, beach & unconsolidated & carnivorous & Tropical/Paulista & $0-30$ \\
\hline \multicolumn{6}{|l|}{ Ranellidae } \\
\hline Cymatium parthenopeum & subtidal & consolidated & carnivorous & Tropical, Paulista and Patagonic & $0-30$ \\
\hline \multicolumn{6}{|l|}{ Muricidae } \\
\hline Chicoreus senegalensis & beach & unconsolidated & carnivorous & Paulista & $0-70$ \\
\hline \multicolumn{6}{|l|}{ Thaididae } \\
\hline Stramonita haemastoma & subtidal & consolidated & carnivorous & Tropical, Paulista and Patagonic & $0-10$ \\
\hline \multicolumn{6}{|l|}{ Nassariidae } \\
\hline Nassarius vibex & $\begin{array}{l}\text { beach, lagoon, } \\
\text { mangrove }\end{array}$ & unconsolidated & necrophagous & Tropical/Paulista & $0-10$ \\
\hline \multicolumn{6}{|l|}{ Fasciolariidae } \\
\hline Fusinus brasiliensis & subtidal & unconsolidated & carnivorous & Tropical/Paulista & $12-50$ \\
\hline Pleuroploca aurantiaca & subtidal & unconsolidated & carnivorous & Tropical/Paulista & $10-50$ \\
\hline \multicolumn{6}{|l|}{ Olividae } \\
\hline Olivancillaria carcellesi & subtidal & unconsolidated & carnivorous & Paulista/Patagonic & $10-30$ \\
\hline Olivancillaria urceus & beach & unconsolidated & carnivorous & Paulista/Patagonic & $0-30$ \\
\hline Olivancillaria vesica auricularia & abeach & unconsolidated & carnivorous & Paulista/Patagonic & $0-30$ \\
\hline Olivancillaria vesica vesica & beach & unconsolidated & carnivorous & Paulista & $0-30$ \\
\hline \multicolumn{6}{|l|}{ Bullidae } \\
\hline Bulla striata & beach & unconsolidated & herbivorous & Tropical/Paulista & $0-10$ \\
\hline \multicolumn{6}{|l|}{ Epitoniidae } \\
\hline Cirsotrema dalli & subtidal & unconsolidated & carnivorous & Tropical/Paulista & $0-30$ \\
\hline
\end{tabular}




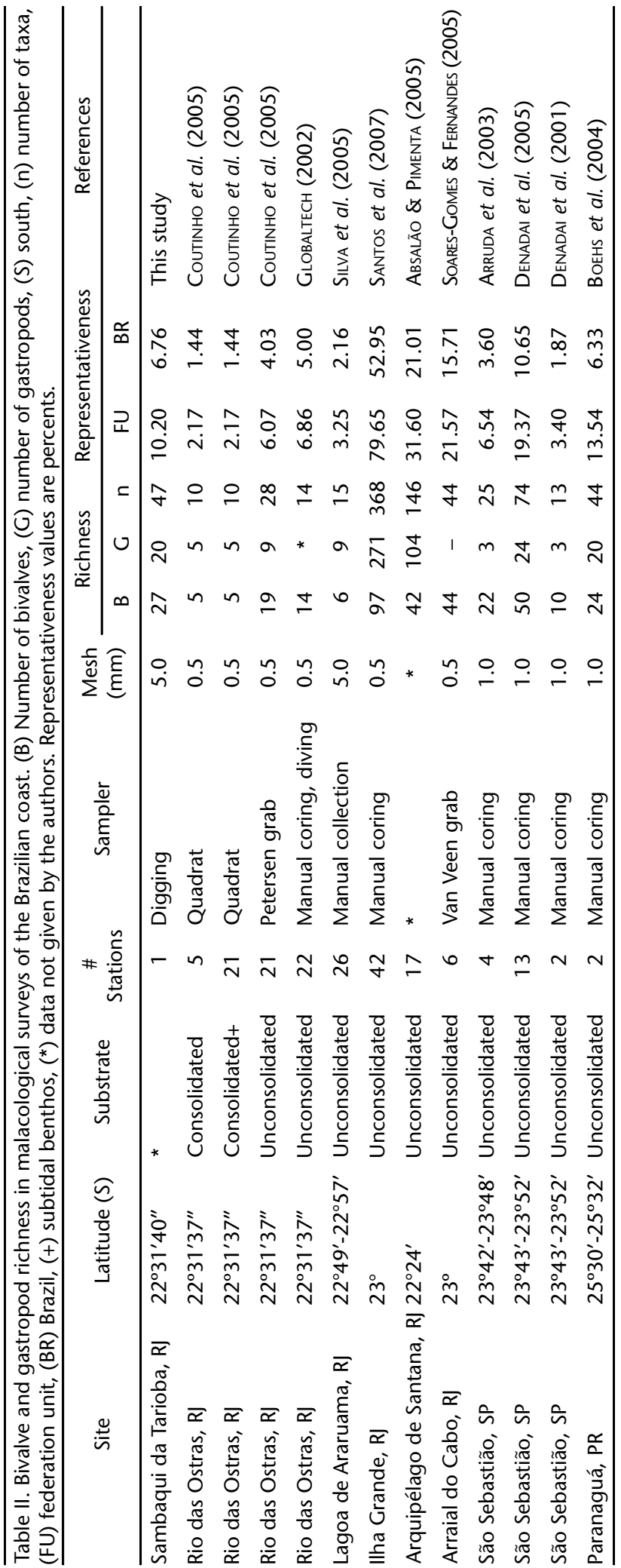

Brazil, few studies have taken this approach, but in recent years knowledge has been increase considerably (CASTILHO \& SimõesLopes 2001, Castilho 2005, Kotzian \& Simões 2006, Rosa 2006, Queiroz \& Carvalho 2008). According to Claassen (1998), investigations on paleoenvironment of a location should begin with simple observation of species proportions and their ecological requirements. Malacological assemblages, which were continuously collected over hundreds or thousands of years, must bear high fidelity to the original communities. Likewise, the presence/absence and the abundance of individuals of each species are frequently enough to establish environmental parameters and to provide an interpretation based on knowledge of the current ecological requirements of the species. Mollusk shells have thus proven to be a powerful tool in paleoenvironmental reconstitution.

Taxonomic list of the species recorded at Tarioba Shellmound makes it possible, from the reconstruction of past mollusk diversity, to use the shellmound as a referential for historical ecology reconstitutions (STAHL 2008). However, a peculiar and quite evident feature of archaeological sites is that the presence of organisms is related to the selectivity of the populations that built them. Diverse factors, such as culture, preferences, technical level, food taboos, and the way the shells were discarded and/or utilized as building material certainly played a relevant role on the composition of the fauna found in shellmounds. Other questions to be considered are differences in species preservation potential and the researcher choices (objectives, excavated area, type of mesh used etc.) (Prummel \& Heinrich 2005).

In his inventory of marine mollusks, Rios (1994) reports a total of 1,575 species for the Brazilian coast. However, new records stemming mainly from studies of descriptions of new species and reports of new occurrences (LEAL 1991, ABSALÃo et al. 1996, Simone 1999, Absalão \& Pimenta 2003, Pimenta \& Absalão 2004, Amaral \& Jablonski 2005) are being added to that inventory. In Rio de Janeiro, about $35 \%$ of those taxa are present, representing a significant fraction of Brazil's entire molluskan fauna (SANTos et al. 2007). According to Rios (1994), Gastropoda is the class that presents greatest richness $(68.8 \%)$, followed by Bivalvia (24.8\%). However, at Tarioba Shellmound this proportion was reversed, with bivalves accounting for $54.7 \%$ of the species, and gastropods, $42.6 \%$. This reversal may have been caused by the habits of the fisher-hunter-gatherers who preferentially collected edible mollusks abundant in the region near the site.

The presence of species at a given site is directly related to their morphofunctional capacity to capture food (ARRUDA et al. 2003). Analysis of the bivalve species found in the shellmound showed a predominance of suspensivorous organisms which probably lived associated to the unconsolidated substrata of beaches. According to McLachlan (1983), the trophic structure of macrofauna from sandy beaches is normally dominated by filtering organisms which significantly contribute as animal bio- 
mass and in recycling nutrients from the sea bottom. The distribution and diversity of these organisms in those areas are determined by physical factors, particularly wave action, sediment particle size, and beach declivity. According to Sanchez-Mata et al. (1993), this guild predominates in fine and medium sand environments, characterized by intertidal regions, mangroves, lagoons and estuaries, places typical of several species of infaunal bivalves which occur at high densities (DAmE 1996). Of the gastropods, most species (65\%) were carnivorous, 35\% herbivorous, and 5\% necrophagous.

The environmental characteristics inferred from the analysis of the mollusks found at Tarioba Shellmound are in agreement with current data (GLOBALtech 2002) for the Rio das Ostras region, which indicate quaternary sediments associated with fluvial/alluvial and marine deposits. The fluvial/alluvial deposits correspond to the Rio das Ostras floodplain, whereas the marine sandy accumulations (marine terraces) and the isolated restingas are composed of fine to medium-sized, well selected, quartzous sands mixed with clay and organic matter. The mangrove areas are composed of a substrate of fine organic clay. The silted lagoon deposits - corresponding to isolated sea arms between restingas - are composed of black peaty clay. It is thus possible to infer that no substantial geomorphological changes seem to have taken place in the Rio das Ostras region and that the paleoenvironment and past molluskan richness coincide with those seen in the present day.

When the shellmound data of the present study are compared to other studies carried out on the Brazilian coast, the representativeness of the former appears to be reduced. However, if one assumes that the shellmound corresponds to an intensive sampling at just one point (or region) of sampling, and that the mesh size used in the sampling is 5 to 10 times greater than that used in other studies, the mollusk record preserved in the shellmound is considerable. The species composition in the shellmound also seems to mirror the present-day biodiversity pattern. Among bivalves, Veneridae Rafinesque, 1815 is the most diverse family worldwide, with about 50 genera (MikKeLsen \& Bieler 2008). In Brazil, 14 genera occur and, of these, nine are represented at Tarioba Shellmound (64.29\%). The family Donacidae Fleming, 1828 is represented by five genera. In Brazil Donax Linnaeus, 1758 and Iphigenia Schumacher, 1817 occur, both represented in the shellmound by the species Donax hanleyanus Philippi, 1842 and Iphigenia brasiliana, both of which being edible (Rios 1994). The family Mytilidae Rafinesque, 1815 was represented only by Mytella charruana (Orbigny, 1842). An interesting datum is that Perna perna (Linnaeus, 1758), another edible mussel, present today in great concentrations on the rocky coasts of Brazil from Espírito Santo to Rio Grande do Sul, has had no valves found at this site. This fact reinforces the idea that this species constitutes a case of bioinvasion in Brazil (SouzA et al. 2003, 2004, 2005, Silveira et al. 2006, Fernandes et al. 2008). In relation to gastropods, the family Olividae Latreille, 1825 had the greatest diversity, genus Olivancillaria Orbigny, 1839 being represented by four species, of which three are considered edible (Rios 1994). The families Naticidae and Fasciolariidae presented two genera and two species each, but for the other families only one species was recorded.

Floeter \& SoARes-Gomes (1999), testing the hypothesis that the Brazilian coast is characterized by three zoogeographical provinces, viz. Tropical, Paulista and Patagonic (PAlacio 1982), concluded that the Paulista province could be characterized merely as a transition zone. Chicoreus senegalensis and Olivancillaria vesica vesica (Gmelin, 1791) were the only species found at Tarioba Shellmound that occurred exclusively in Paulista province. The other bivalve and gastropod species found in the shellmound occurred in the Tropical, Paulista and Patagonic provinces. Thus, according to Floeter \& SoARes-Gomes (1999), the data from Tarioba Shellmound do not indicate any specificity of the Paulista province even as far back as 4,000 years ago.

In conclusion, the data obtained from Tarioba Shellmound indicate little or no evolution of the patterns of composition, richness and distribution of molluskan biodiversity in the Rio das Ostras region. Likewise, the reconstitution of paleoenvironmental characteristics seems to also demonstrate that the geomorphological and climatic features of the area remained mostly unchanged in the last 4,000 years BP.

\section{ACKNOWLEDGEMENTS}

This work was financially supported by Brazilian Scientific Council (CNPq, 477818/2006-4) and Rio de Janeiro Foundation for Supporting Research (FAPERJ, Doctorate scholarship for R.C.C.L. Souza). This research was developed in the area of the Museu do Sambaqui da Tarioba, Rio das Ostras, RJ, Brazil established by researchers from Instituto de Arqueologia BrasileiroIAB under coordination of Ondemar Dias e Paulo Seda in agreement with the Fundação Casa de Cultura de Rio das Ostras.

\section{LITERATURE CITED}

Аввотт, R.T. 1974. American seashells. New York, van Nostrand Reinhold, 663p.

Absalão, R.S. \& A.D. Pimenta. 2003. A new subgenus and three new species of Brazilian deep waters Olivella (Mollusca, Gastropoda, Olivellidae) collected by the RV Marion Dufresne in 1987. Zoosystema 25: 177-185.

Absalão, R.S. \& A.D. Pimenta. 2005. Moluscos Marinhos da APA do Arquipélago de Santana, Macaé, RJ. Rio de Janeiro, Editora Ciência Moderna, 84p.

Absalão, R.S.; A.D. Pimenta \& P.M. Costa. 1996. Novas ocorrências de gastrópodes no litoral do Rio de Janeiro (Brasil). Nerítica 10: 57-68.

AMARAL, A.C.Z. \& S. JABLONSKI. 2005. Conservation of marine and coastal biodiversity in Brazil. Conservation Biology 19: 625631.

Amaral, A.C.Z.; A.E. Rizzo \& E.P. Arruda. 2005. Manual de Identificação dos invertebrados marinhos da região sudeste- 
sul do Brasil. São Paulo, Editora da Universidade de São Paulo, 288p.

Andrade Lima, T.; K.D. Macario; R.M. Anjos; P.R.S. Gomes; M.M. Coimbra \& E. Elmore. 2002. The antiquity of the prehistoric settlement of the central-south Brazilian coast. Radiocarbon 44 (3): 733-738.

Andrade Lima, T.; K.D. Macario; R.M. Anjos; P.R.S. Gomes; M.M. Cormbra \& E. Elmore. 2003. AMS dating of early shellmounds of the southeastern Brazilian coast. Brazilian Journal of Physics 33 (2): 276-79.

Araújo, M.B. \& C. Rahbek. 2006. How does climate change affect biodiversity? Science 313: 1396-1397.

Arruda, E.P.; O. Domaneschi; A.C.Z. Amaral. 2003. Mollusc feeding guilds on sandy beaches in São Paulo state, Brazil. Marine Biology 143: 691-701.

Boehs, G.; T.M. Absher \& A. Cruz-Kaled. 2004. Composition and distribution of benthic molluscs on intertidal flats of Paranaguá Bay (Paraná, Brazil). 2004. Scientia Marina 68 (4): 537-543.

CASTILHO, P.V. 2005. Utilization of cetaceans in shell mounds from the southern coast of Brazil. Quaternary International 180: 107-114.

Castilho, P.V. \& P.C. Simões-Lopes. 2001. Zooarqueologia dos mamíferos aquáticos e semi-aquáticos da Ilha de Santana, sul do Brasil. Revista Brasileira de Zoologia 18 (3): 719727.

ClaAssen, C. 1998. Shells. Cambridge Manuals in Archaeology Series. Cambridge, Unversity Press, XIV+266p.

Coutinho, R.; J.S.V. Silva; R.C.C.L. SouZa; C.E.L. Ferreira; W.M. Ribas; M.H.B. Neves; L.R. Gaelzer; J.E.A. Gonçalves \& J.D. Nogueira Junior. 2005. Levantamento Ecológico da Região Costeira de Rio das Ostras. Arraial do Cabo, Coutinho S.A, $36 \mathrm{p}$.

DAME, R.F. 1996. Ecology of marine bivalves: an ecosystem approach. Boca Raton, CRC Press, 254p.

Denadai, M.R.; A.C.Z. Amaral \& A. Turra. 2001. Spatial distribution of molluscs on sandy intertidal substrates with rock fragments in south-eastern Brazil. Estuarine, Coastal and Shelf Science 53: 733-743.

Denadai, M.R.; A.C.Z. Amaral \& A. Turra. 2005. Structure of molluscan assemblages in sheltered intertidal unconsolidated environments. Brazilian Archives of Biology and Technology 48 (5): 825-839.

Dias, O. 2001. O Sambaqui da Tarioba, p. 37-50. In: O. DiAs; J. Decco \& M. M. Fróes (Ed.). A pré-história de Rio das Ostras: sítio arqueológico Sambaqui da Tarioba. Rio das Ostras. Rio de Janeiro, Inside, 110p.

Di CASTRI, F. 1989. History of biological invasions with special emphasis on the Old World, p. 1-26. In: J.A. DraKe; H.A. Mooney; F. Di Castri; R.H. Groves; F.J. Kruger; M. Rejmanek \& M. Williamson (Eds). Biological invasions: a global perspective. New York, Wiley and Sons, 550p.

Didham, R.K.; J.M. Tylianakis; M.A. Hutchison; R.M. Ewers \& N.J.
GeMmEL. 2005. Are invasive species the drivers of ecological change? Trends in Ecology and Evolution 20: 470-474.

Fernandes, F.C.; R.C.C.L. Souza; A.O.R. JunQueIra; L.C. Rapagnã \& A. Breves-Ramos. 2008. Distribuição mundial e o impacto de sua introdução no Brasil, p. 25-30. In: C. Resgalla Jr; L.I. Weber \& M.B. Conceição (Eds). O Mexilhão Perna perna (L.): Biologia, Ecologia e Aplicações. Rio de Janeiro, Editora Interciência, 324p.

Figuti, L. 1993. O homem pré-histórico, o molusco e o sambaqui. Revista do Museu de Arqueologia e Etnologia 3: 67-80.

Floeter, S.R. \& A. SoAres-Gomes. 1999. Biogeographic and species richness patterns of Gastropoda on the Southwestern Atlantic. Revista Brasileira de Biologia 59 (4): 567-575.

Froyd, C.A. \& K.J. Willis. 2008. Emerging issues in biodiversity $\&$ conservation management: the need for a palaeoecological perspective. Quaternary Science Reviews 27: 1723-1732.

Furon, R. 1969. La distribución de los seres. Barcelona, Editorial Labor, 163p.

Fürsich, F.T. 1995. Approaches to palaeoenvironmental reconstructions. GEOBIOS 18: 183-195.

Garcia-Cubas, A. 1981. Moluscos de un sistema lagunar tropical en el sur del golfo de México (Laguna de Términos, Campeche). Publicaciones Especiales del Instituto de ciências del Mar y Limnologia de la Universidad Nacional Autônoma de México 5: 1-182.

Globaltech-Tecnologia Ambiental. 2002. Projeto do Futuro Emissário Submarino em Rio das Ostras. Rio de Janeiro, Globaltech Tecnologia Ambiental, 105p.

KotZian, C.B. \& M.G. SimÕES. 2006. Taphonomy of recent freshwater molluscan death assemblages, Touro Passos stream, southern Brazil. Revista Brasileira de Paleontologia 9 (2): 243-260.

LEAL, J.H. 1991. Marine prosobranch gastropods from oceanic islands off Brazil: species composition and biogeography. Oegstgeest, Universal Book Service, Dr W. Backhuys, 436p.

Lima, T.A. 2000. Em busca dos frutos do mar: os pescadorescoletores do litoral centro-sul do Brasil. Revista da Universidade de São Paulo 44: 270-327.

Lindbladh, M.; J. Brunet; G. Hannon; M. NikLasson; P. Eliasson; G. ERIKSSON \& A. EKSTRAND. 2007. Forest history as a basis for ecosystem restoration: a multidisciplinary case study in a south Swedish temperate landscape. Restoration Ecology 15: 284-295.

McLachlan, A. 1983. Sand beach ecology: a review, p. 321-381. In: A. Mclachlan \& T. Erasmus (Eds). Sandy beaches as ecosystems. Junk, The Hague, 753p.

Merlano, J.M.D. \& M.P. Hegedus. 1994. Moluscos del caribe colombiano. Um catálogo ilustrado. Bogotá, Colciencias, Fundación Natura, Invemar, LXXIV+291p.

Mikkelsen, P.M. \& R. Bieler. 2008. Seashells of Southern Florida: living marine bivalves of the Florida keys and adjacent regions. New Jersey, Princeton University Press, 503p. 
Millar, C.I. \& W. Wolfenden. 1999. The role of climate change in interpreting historic variability. Ecological Applications 9: 1207-1216.

Palacio, F.J. 1982. Revisión zoogeográfica marina del sur del Brasil. Boletim do Instituto Oceanográfico 31 (1): 69-92.

Pearson, R.G. \& T.P. Dawson. 2003. Predicting the impacts of climate change on the distribution of species: are bioclimate envelope models useful? Global Ecology \& Biogeography 12: 361-371.

Pimenta, A.D. \& R.S. Absalão. 2004. Fifteen new species and ten new records of Turbonilla Risso, 1826 (Gastropoda, Heterobranchia, Pyramidellidae) from Brazil. Bolletino Malacologico 39: 113-140.

Prummel, W. \& D. Heinrich. 2005. Archaeological evidence of former occurrence and changes in fishes, amphibians, birds, mammals and molluscs in the Wadden Sea area. Marine Research 59 (1): 55-70.

Queiroz, A.N. \& O.A. Carvalho. 2008. Problems in the interpretation of Brazilian archaeofaunas: different contexts and the important role of taphonomy. Quaternary International 180: 75-89.

Reitz, E. J. \& E. S. Wing. 2008. Zooarchaeology. Cambridge, Cambridge University Press, 455p.

Rios, E.C. 1994. Seashells of Brazil. Rio Grande, Fundação Universidade Federal Rio Grande, 113+492p.

Rosa, A.O. 2006. Composição e diversidade da arqueofauna dos sítios de Içara: SC-IÇ-01 e SC-IÇ-06. Pesquisas 63: 33-53.

Roy, K. ; D. Jablonski \& J.W. Valentine . 2001. Climate change, species range limits and body size in marine bivalves. Ecology Letters 4: 366-370.

Sanchez-Mata, A.; J. Mora; J.M. Garmendia \& M. Lastra. 1993. Estructura trófica del macrozoobentos submareal de la ría de Ares-Betanzos. I: Composición y distribución. Publicaciones Especiales - Instituto Español de Oceanografía 11: 33-40.

Santos, F.N.; C.H.S. Caetano; R.S. Absalão \& T. S. Paula. 2007. Mollusca de substrato não consolidado, p. 207-236. In: J.C. Creed; D.O. Pires \& M.A.O. Figueiredo (Eds). Biodiversidade Marinha da Baía da Ilha Grande. Brasília, Ministério do Meio Ambiente, 416p.

Scheel-Ybert, R.; D. Klökler; M.D. Gaspar \& L. Figuti. 2006. Proposta de amostragem padronizada para macro-vestígios bioarqueológicos: antracologia, arqueobotânica, zooarqueologia. Revista do Museu de Arqueologia e Etnologia 1516: 139-163.

Silva, E.P.; A. Soares-Gomes; F. Fernandes \& C.M. Abreu. 2005. Sandy beach macrobenthos assemblages at a hypersaline coastal lagoon, Lagoa de Araruama, RJ, Brasil. Journal of Coastal Research 42: 265-270.

Silveira, N.G.; Souza, R.C.C.L.; F.C. Fernandes \& E.P. Silva. 2006. Occurrence of Perna perna, Modiolus carvalhoi (Mollusca, Bivalvia, Mytilidae) and Megabalanus coccopoma (Crustacea, Cirripedia) off Areia Branca, Rio Grande do Norte state, Brazil. Biociências 14 (1): 89-90.

SimONE, L.R.L. 1999. Comparative morphology and systematics of Brazilian Terebridae (Mollusca, Gastropoda, Conoidea), with descriptions of three new species. Zoosystema 21: 199-248.

SouZA, R.C.C.L.; F.C. Fernandes \& E.P. Silva. 2003. A study on the occurrence of the brown mussel Perna perna on the sambaquis of the Brazilian coast. Revista do Museu de Arqueologia e Etnologia 13: 3-24.

SouZA, R.C.C.L.; F.C. Fernandes \& E.P. Silva. 2004. Distribuição atual do mexilhão Perna perna no mundo: um caso recente de bioinvasão, p. 157-172. In: J.S.V. Silva \& R.C.C.L. SouZA (Eds). Água de Lastro e Bioinvasão. Rio de Janeiro, Editora Interciência, 224p.

Souza, R.C.C.L.; F.C. Fernandes \& E.P. SiLva. 2005. Sambaqui: um baú de preciosas informações. Ciência Hoje 214: 72-74.

SoARes-Gomes, A. \& F.C. Fernandes. 2005. Spatial distribution of bivalve mollusc assemblages in the upwelling ecosystem of the continental shelf of Cabo Frio, Rio de Janeiro, Brazil. Revista Brasileira de Zoologia 22 (1): 73-80.

STAHL, P.W. 2008. The contributions of zooarchaeology to historical ecology in the neotropics. Quaternary International 180: 516.

Stein, J.K. 1992. The analysis of shell middens, p. 1-24. In: J.K. Stein (Ed.). Deciphering a shell midden. San Diego, Academic Press, 375p.

TCHernov, E. 1992. Evolution of complexities, exploitation of the biosphere and zooarchaeology. Archaeozoologia 5 (1): 9-42.

Willis, K.J. \& H.J.B. BIRKs. 2006. What is natural? The need for a long-term perspective in biodiversity and conservation. Science 314: 1261-1265.

Submitted: 15.VI.2009; Accepted: 30.III.2010.

Editorial responsibility: Paulo da Cunha Lana 